\title{
Determination and Interpretation of the Norm Values of PreSchool Social Skills Rating Scale Teacher Form
}

\author{
Esra Omeroglu ${ }^{a}$ \\ Gazi University \\ Sener Buyukozturk ${ }^{\mathrm{b}}$ \\ Hasan Kalyoncu University \\ Yasemin Aydogan ${ }^{c}$ \\ Abant Izzet Baysal University
}

\section{Mehtap Cakan ${ }^{\mathrm{d}}$}

Gazi University

\section{Ebru Kilic Cakmak \\ Gazi University}

\author{
Arzu Ozyurek ${ }^{f}$ \\ Karabuk University
}

\author{
Gulumser Gultekin Akduman ${ }^{9}$ \\ Gazi University
}

\author{
Yunus Gunindi ${ }^{\text {h }}$ \\ Aksaray University \\ Omer Kutlui \\ Ankara University
}

Aysel Coban ${ }^{\mathrm{j}}$

Hacettepe University

\section{Ozlem Yurt ${ }^{\mathrm{k}}$}

Karadeniz Technical University

\author{
Hakan Kogar \\ Baskent University
}

\author{
Seda Karayol ${ }^{\mathrm{m}}$ \\ Mugla Sitki Kocman University
}

\begin{abstract}
This study aimed to determine and interpret norms of the Preschool Social Skills Rating Scale (PSSRS) teacher form. The sample included 224 independent preschools and 169 primary schools. The schools are distributed among 48 provinces and 3324 children were included. Data were obtained from the PSSRS teacher form. The validity and reliability evidence was re-obtained from the norm sample, and it was concluded that the sample preserved the structure comprising 4 factors and 49 items. The alpha coefficient obtained from the PSSRS for the whole norm sample was determined at 0.96. PSSRS norm values were obtained for four factors and the total scale at each age. Children's social development skills are interpreted in accordance with the percentile norms pie charts, which include the total scores from the full scale score and sub-scales. Findings obtained with regard to the validity and reliability of PSSRS scores indicated that the scale can be used as an auxiliary tool in determining children's social skill levels. Consequently, children's PSSRS scores should be recorded and compared to future results, and the degree of improvement should be assessed. Furthermore, each child should be evaluated individually. It is important to consider children's ages and other developmental characteristics when interpreting the results of the scale.
\end{abstract}

Keywords: Social skill $\bullet$ Validity $\bullet$ Reliability $\bullet$ Norm study 
That a child is raised to exhibit behaviors as expected by the society depends on social development. In this respect, children's social development in their early years constitutes the basis of their future social behaviors (Çubukçu \& Gültekin, 2000). Social and emotional development is the process of learning the skills, approaches, and values that individuals develop to gain social and emotional competence (Elias et al., 1997).

The most important person in teaching social skills is the teacher, who uses various strategies to teach the skills necessary for establishing and maintaining relationships with peers, self-control, adaptability to the environment, maintaining work in a group, coping with aggressive behaviors and stress, devising plans, and problem solving. Teachers achieve success in helping children internalize rules using positive guidance techniques and becoming models of inspiration themselves (Wortham, 1998). Furthermore, teachers who undertake new professional roles and responsibilities brought about by changing and developing educational processes around the world not only teach but also develop values, conduct research, overcome challenges, establish interdisciplinary relations, question, produce, and attach importance to communication and advice. However, overall, instructors should first engage in self-development to teach children social skills (Çivitçi \& Çivitçi, 2009).

Developing children's personal and social as well as academic skills is among the fundamental goals of teachers who potently interact with children and are responsible for teaching them basic knowledge, skills, behaviors, and habits (Akkök, 2006).

In this process, the teacher determines objectives with regard to social skills, checks learning groups, determines necessary special skills for children working together to solve problems, obtains children's opinions to be able to develop group work, lists social skills to be taught in each group, and analyzes required social skills in a particular subject. Furthermore, the teacher observes and records children's social skills. Teacher behaviors constitute the basis of behavioral examples of children with their friends in preschool education institutions. Teachers also mold the experiences for children to develop their speaking skills, respect others' rights, wait in a queue, conflict

* This study is a part of TUBITAK KAMAG project (project number 109G047) and project coordinator is Prof. Esra Ömeroḡlu.

a Prof. Esra Omeroglu (PhD), Gazi Faculty of Education, Gazi University, Ankara Turkey Email: e.omerogludagmail.com

b Prof. Sener Buyukozturk (PhD), Faculty of Education, Hasan Kalyoncu University, Gaziantep Turkey Email: senerbuyukozturkagmail.com

c Assoc. Prof. Yasemin Aydogan (PhD), Faculty of Education, Abant İzzet Baysal University, Bolu Turkey Email: yaseminaydogandyahoo.com

d Prof. Mehtap Cakan (PhD), Gazi Faculty of Education, Gazi University, Ankara Turkey Email: cakanmehtaplahotmail.com

e Assoc. Prof. Ebru Kilic Cakmak (PhD), Gazi Faculty of Education, Gazi University, Ankara Turkey Email: ebrukilicagmail.com

f Assoc. Prof. Arzu Ozyurek (PhD), Health High School, Karabük University, Karabük Turkey Email: a.ozyurekakarabuk.edu.tr

g Assoc. Prof. Gulumser Gultekin Akduman (PhD), Gazi Faculty of Education, Gazi University, Ankara Turkey Email: gulumsergultekinđyahoo.com

h Assist. Prof. Yunus Gunindi (PhD), Faculty of Education, Aksaray University, Aksaray Turkey Email: ygunindidgmail.com

i Assist. Prof. Omer Kutlu (PhD), Faculty of Educational Sciences, Ankara University, Ankara Turkey Email: kutluomer57dyahoo.com

j Assoc. Prof. Aysel Coban (PhD), Faculty of Education, Hacettepe University, Ankara Turkey Email: a.cobanabaskent.edu.tr

k Assoc. Prof. Ozlem Yurt (PhD), Fatih Faculty of Education, Karadeniz Technical University, Trabzon Turkey Email: ozlemyuırt37agmail.com

I Corresponding author Hakan Kogar (PhD), Faculty of Education, Başkent University, Baḡlıca Kampusü Eskișehir Yolu 20. Km. Ankara 06530 Turkey

Research areas: Measurement theories; Scale development; Multivariate statistics Email: hkogardgmail.com

m Seda Karayol, Faculty of Education, Muḡla Sıtkı Koçman University, Muḡla Turkey Email: seda_karacelikahotmail.com 
resolution, to solve social problems, and develop empathy in oneself (Beaty, 2006, cited in Kamaraj, 2008; Şimşek, Doymuş, \& Şimşek, 2008).

According to Sanders and Rivers (1996), teacher qualifications include professional capability, knowledge of the state of education, field knowledge, teaching experiences, and social capabilities. In addition, organizational planning and teaching approaches, occupational professionalism, and social skills have come to the fore in recent years as skills that teachers must possess (as cited in Seven \& Yoldaş, 2007). Teachers are expected to be emotionally and socially sensitive while handling children's social problems and concerns (Yüksel, 2001).

Many studies have determined that social skills training in preschool education has positive effects on children's social skills. In social skill training programs, the use of modeling, guidance, behavioral repetitions, participating, feedback, and reinforcement skills are among behavioral strategies for developing special social skill reactions (Gresham, 1981, 1985; McIntosh, Vaughn, \& Zaragoza, 1991; Verduyn, Lord, \& Forrest, 1990).

In addition, social skills and the quality of social capabilities can be increased through studies aimed at increasing social capabilities. At the preschool stage, assessment of social skills has particular importance. Many methods such as direct behavioral observation, grading scales, self-assessment, and sociometry are used in assessment of social skills (Kapikıran, İvrendi, \& Adak, 2006). After assessment, it is possible to try different solutions to eliminate children's social deficiencies and develop their social skills.

Because preschool years are the most productive time for providing children training in social skills, the development and effective use of measuring tools that provide data required by instructors and educators to guide their studies on supporting children's social skills gain great importance. Starting from these necessities, the Preschool Social Skills Rating Scale (PSSRS) was developed within the scope of the "Preschool Social Skills Support Project" supported by the Scientific and Technological Research Council of Turkey (TUBITAK), and the scale was aimed to expand its utility. The PSSRS was, in fact, developed as two different scale forms-parent and teacher. This research aims to reflect studies on the teacher form. The Preschool Social Skills Rating Scale (PSSRS) was developed for preschool children in accordance with the Turkish culture.

This study's objective is to discover Turkish norms for the teacher form of the Preschool Social Skills
Rating Scale (PSSRS), developed to assess social skills of 36-72-month-old children. With Turkish norm values, the scale will provide information about social skill levels by comparing children's development with those of peers of the same age and gender. Thus, the PSSRS will provide valuable data for adults and researchers.

\section{Method}

\section{Research Group}

To collect data required for the PSSRS Turkish norm study, stratified sampling was used, and schools were the sample units. A framework was provided only for the pre-units (schools) through a two-

\begin{tabular}{|c|c|c|c|}
\hline \multicolumn{4}{|c|}{$\begin{array}{l}\text { Table } 1 \\
\text { Distribution of the Provinces and School Numbers Included in } \\
\text { the Sample by NUTS1 }\end{array}$} \\
\hline Region Code & $\begin{array}{l}\text { Provinces } \\
\text { Included in } \\
\text { the Sample }\end{array}$ & $\begin{array}{l}\text { Sample } \\
\text { School } \\
\text { Number }\end{array}$ & $\begin{array}{l}\text { Number of } \\
\text { Schools that } \\
\text { Performed } \\
\text { an Applica- } \\
\text { tion }\end{array}$ \\
\hline TR1: ISTANBUL & İstanbul & 27 & 27 \\
\hline $\begin{array}{l}\text { TR2: WESTERN } \\
\text { MARMARA }\end{array}$ & $\begin{array}{l}\text { Edirne, } \\
\text { Tekirdağ, } \\
\text { Balıkesir }\end{array}$ & 17 & 17 \\
\hline TR3: AEGEAN & $\begin{array}{l}\text { İzmir, } \\
\text { Aydın,Muğ- } \\
\text { la, Afyon, } \\
\text { Kütahya, } \\
\text { Uşak }\end{array}$ & 53 & 54 \\
\hline $\begin{array}{l}\text { TR4: EASTERN } \\
\text { MARMARA }\end{array}$ & $\begin{array}{l}\text { Bursa, Bolu, } \\
\text { Kocaeli, } \\
\text { Eskișehir }\end{array}$ & 35 & 35 \\
\hline $\begin{array}{l}\text { TR5: WESTERN } \\
\text { ANATOLIA }\end{array}$ & $\begin{array}{l}\text { Ankara, } \\
\text { Konya }\end{array}$ & 32 & 31 \\
\hline $\begin{array}{l}\text { TR6: MEDITERRA- } \\
\text { NEAN }\end{array}$ & $\begin{array}{l}\text { Antalya, } \\
\text { Isparta, } \\
\text { Adana, Mer- } \\
\text { sin, Hatay, } \\
\text { Kahraman- } \\
\text { maraş }\end{array}$ & 47 & 48 \\
\hline $\begin{array}{l}\text { TR7: CENTRAL } \\
\text { ANATOLIA }\end{array}$ & $\begin{array}{l}\text { Kırıkkale, } \\
\text { Kayseri, } \\
\text { Niğde, Sivas, } \\
\text { Yozgat }\end{array}$ & 31 & 32 \\
\hline $\begin{array}{l}\text { TR8: WESTERN } \\
\text { BLACK SEA }\end{array}$ & $\begin{array}{l}\text { Karabük, } \\
\text { Zonguldak, } \\
\text { Amasya, } \\
\text { Samsun }\end{array}$ & 28 & 28 \\
\hline $\begin{array}{l}\text { TR9: EASTERN } \\
\text { BLACK SEA }\end{array}$ & $\begin{array}{l}\text { Trabzon, } \\
\text { Ordu, Art- } \\
\text { vin, Giresun }\end{array}$ & 30 & 30 \\
\hline $\begin{array}{l}\text { TRA: } \\
\text { NORTH-EASTERN } \\
\text { ANATOLIA }\end{array}$ & $\begin{array}{l}\text { Erzincan, } \\
\text { Erzurum, } \\
\text { Ardahan }\end{array}$ & 17 & 17 \\
\hline $\begin{array}{l}\text { TRB: MIDDLE } \\
\text { EASTERN ANA- } \\
\text { TOLIA }\end{array}$ & $\begin{array}{l}\text { Elazı̆̆, } \\
\text { Malatya, } \\
\text { Bitlis, Van }\end{array}$ & 25 & 25 \\
\hline $\begin{array}{l}\text { TRC: SOUTHEAST- } \\
\text { ERN ANATOLIA }\end{array}$ & $\begin{array}{l}\text { Gaziantep, } \\
\text { Diyarbakir, } \\
\text { Şanlıurfa, } \\
\text { Batman, } \\
\text { Mardin, } \\
\text { Siirt }\end{array}$ & 51 & 51 \\
\hline TOTAL & 48 & 393 & 395 \\
\hline
\end{tabular}


stage sampling method to decrease labor and cost. Indeed, two-stage sampling is more advantageous than other sampling methods even in estimation results with low sensitivity (Tryfos, 1996). Schools were grouped as independent preschools and primary schools with nurseries. Accordingly, the total number of schools in the research for the 2011-2012 school year is 23653, of which 22195 are primary schools and 1458 are independent preschools. Sample size was first determined as 378 with a sensitivity of $5 \%$ and a confidence level of $95 \%$. Then, sample size was determined as 393 , with 15 extra schools, considering practice risks. Schools in the sample were chosen through simple random sampling from the school list, so that 224 are independent preschools, and 169 are primary schools. The schools are distributed among 48 provinces. A practice was performed in all schools included in the sample. The distribution of schools where NUTS1 conducted the practice is shown in Table 1. The practices began on 18 April 2012, and ended on 8 June 2012.

The practice was performed in 168 of the planned primary schools, but it could not be performed in one school because of a permission problem. The practice was applied in all 224 independent preschools as planned, and also in three extra, independent primary schools, considering the risks of practice problems and that there are not enough children at schools. Hence, the practice was performed in 227 independent preschools in total and 395 educational institutions in general.

A larger sample than planned was achieved thanks to managers and teachers' support at schools included in the sample, and the fact that they allowed the practice to be performed in all classes. Consequently, 2541 preschool children were reached with 450 teacher forms for 3-year-olds, 851 teacher forms for 4-year-olds, and 1240 teacher forms for 5-year-olds. Data for 3324 children in total were obtained, with, additionally, 738 teacher forms in preschools within primary schools for 5-year-olds.

Of 3324 children for whom PSSRS teacher forms were completed, 1650 are female (1264 from preschools, 386 from primary schools) and 1674 are male (1227 from preschools, 397 from primary schools).

Some items in certain forms were left blank. The data on children for whom $10 \%$ or more of the scale items were not completed were excluded from the dataset. It is known that estimated values deviate from real data at a certain rate no matter through which method allocation is made for lost data (Akbaş, 2014). Lost data allocation was not needed in this study, however, because of the large sample. Besides, frequency distributions were examined to determine children's change by gender and age variables by excluding 229 children due to lost data from the practice sample.

\section{Table 2}

Frequency Distributions of the Sample According to Age and Gender

\begin{tabular}{|c|c|c|c|c|c|}
\hline \multirow[t]{2}{*}{ Variable } & \multirow[t]{2}{*}{ Category } & \multicolumn{2}{|c|}{$\begin{array}{l}\text { Whole sample } \\
\quad(n=3324)\end{array}$} & \multicolumn{2}{|c|}{$\begin{array}{l}\text { Last sample } \\
(n=3095)\end{array}$} \\
\hline & & $f$ & $\%$ & $f$ & $\%$ \\
\hline \multirow{2}{*}{ Gender } & Female & 1650 & 49.6 & 1542 & 49.8 \\
\hline & Male & 1674 & 50.4 & 1553 & 50.2 \\
\hline \multirow{3}{*}{ Age } & 3 years & 453 & 13.6 & 428 & 13.8 \\
\hline & 4 years & 901 & 27.1 & 850 & 27.5 \\
\hline & 5 years & 1970 & 59.3 & 1817 & 58.7 \\
\hline
\end{tabular}

Table 2 demonstrates that frequency distributions by gender and age of the sample subject to analysis obtained by excluding lost data and the frequency distribution of all children included in the sample are close to each other, so the respondent profile does not change. According to this result, individuals excluded due to lost data do not lead to bias related to sample profile change.

Besides, whether 229 children excluded from the sample due to lost data cause bias in the dataset's findings was additionally examined using twoway ANOVA. In the analysis, the significance of the mutual effects of the group variable (subgroups with lost data and the lost data extracted) with gender and age factors on scale scores were observed. Two-factor ANOVA results for group ${ }^{*}$ age and group ${ }^{\star}$ gender are shown in Table 2.

\begin{tabular}{lccccccccc}
\hline $\begin{array}{l}\text { Table 3 } \\
\text { Examination of Sample Bias by Age and Gender Using ANOVA }\end{array}$ \\
\hline $\begin{array}{l}\text { Effect } \\
\text { Test }\end{array}$ & $\begin{array}{c}\text { Initial } \\
\text { skills }\end{array}$ & $\begin{array}{c}\text { Academic } \\
\text { skills }\end{array}$ & $\begin{array}{c}\text { Friendship } \\
\text { skills }\end{array}$ & $\begin{array}{c}\text { Emotional } \\
\text { Man- } \\
\text { agement } \\
\text { Skills }\end{array}$ \\
\cline { 2 - 10 } & $F$ & $p$ & $F$ & $p$ & $F$ & $p$ & $F$ & $p$ \\
\hline $\begin{array}{l}\text { Group } \\
\text { Age }\end{array}$ & 2.01 & .156 & 0.18 & .673 & 0.31 & .576 & 0.18 & .670 \\
$\begin{array}{l}\text { Group } \\
\text { Gender }\end{array}$ & 0.03 & .869 & 0.30 & .582 & 0.20 & .652 & 0.07 & .789 \\
\hline
\end{tabular}

Table 3 shows that the mutual effects of groupgender and group-age variables on all factor scores of the PSSRS teacher form were not significant. In other words, children excluded did not cause a difference in gender and age levels on scale scores. Accordingly, exclusions due to lost data did not lead to bias. 


\section{Data Collection Tools}

The five-factor structure of the PSSRS teacher form, of which the corporate framework is defined and supported by expert opinion, was examined using Confirmatory Factor Analysis (CFA). According to CFA results, the five-factor structure does not sufficiently conform to the data collected. Examination of modification data revealed that the fifth factor "self-control skills" and the fourth factor "emotion management skills" are not differentiated, and three factors $(38,39$, and 42$)$ yield a high level of relationship among many items within factor and in other factors. Based on expert opinion, it was decided to re-define the item "expressing one's emotions" (37) in the managing emotions factor as the initial skills factor, the "listening" skill in the initial skills factor as "Academic Support Skills," and the fourth and fifth factors as "Emotion Management Skills." Thus, a fourfactor structure with 39 items was repeated for model data compatibility. That $\left(\chi^{2} / s d\right)$ among compliance statistics remains below 5 (Sümer, 2000), that RMSEA and RMR values are lower than .08 (Sümer, 2000), and that even this value remains below 10 (Anderson \& Gerbing, 1984; Cole, 1987; Marsh, Balla, \& McDonald, 1988) means the structure is deemed acceptable for model data compliance. On the other hand, that CFI, $\mathrm{NFI}$, and GFI values remain above .90 is also regarded as good compliance (Anderson \& Gerbing, 1984; Cole, 1987; Marsh, Balla, \& McDonald, 1988). When analysis results (Table 4) are examined, the RMSEA value for the four-factor model is just above .08, which is the acceptance limit for model data compliance, relatively low when compared to GFI level; however $\left(\chi^{2} / s \mathrm{~d}\right)$ is below 5 , the RMR value is below .08, and CFI and NFI levels are above .90. According to these results, data compliance of the model scale consisting of a four-factor structure is at an acceptable level, despite not being good.

The path diagram on PSSRS four-factor structure is shown in Figure 1, where all standardized coefficients showing items' relationship with their factors are above .45. Standardized coefficients showing the relationship between factors are shown in Table 5.

\section{Table 5}

PSSRS Teacher Form Relationship Between Factors: Standardized Coefficients

\begin{tabular}{lcccc}
\hline Factors & 1 & 2 & 3 & 4 \\
\hline 1. Initial & - & & & \\
2. Academic Support & .79 & - & & \\
3. Friendship & .75 & .85 & - & \\
4. Managing Emotions & .57 & .72 & .79 & - \\
\hline
\end{tabular}

Table 5 reveals a middle and high level of relationship between factors. This result shows that the four basic skills defined as social skills' sub-dimensions are not independent of one another. In this study, the scale's four-factor structure was re-examined based on data obtained from the norm sample.

The scale's psychometric properties were reexamined using data obtained from the norm sample. In the norm sample, the number of teacher forms filled in is 3324 . If $10 \%$ or more of scale items were not completed, those forms were excluded from the dataset. A single data file was obtained for a total of 3095 children.

CFA results of the scale's four-factor structure are shown in Table 6 .

According to Table 6, the chi-square value is quite high, increasing with increased sample size. Thus, the calculation and interpretation of the chi-square and accordingly calculated " $\chi^{2} / \mathrm{sd}$ " value are not meaningful, especially in very large samples. While the GFI value in compliance statistics is low, that RMSEA and RMR values in particular are at acceptable limits, and that CFI and NFI values are high shows that model data compliance is ensured in the four-factor structure.

Table 7 displays alpha internal consistency coefficients calculated for the scale scores' reliability.

Table 4

PSSRS Teacher Form Confirmatory Factor Analysis Results: Compliance Statistics

\begin{tabular}{|c|c|c|c|c|c|c|c|c|}
\hline Model & $x^{2}$ & $s d$ & $\left(\chi^{2} / \mathrm{sd}\right)$ & RMSEA & RMR & $\mathrm{CFI}$ & NFI & GFI \\
\hline 1. Model: Five-Factor Structure (52 items) & 8113.27 & 1264 & 6.41 & .14 & .10 & .95 & .93 & .47 \\
\hline $\begin{array}{l}\text { 2. Model: Four-Factor Structure (49 items)-Final } \\
\text { Model }\end{array}$ & 5238.00 & 1117 & 4.69 & .09 & .06 & .96 & .95 & .66 \\
\hline
\end{tabular}

Table 6

CFA Results for PSSRS Four-Factor Model

\begin{tabular}{lccccccc}
\hline Model & $\chi^{2}$ & $s d$ & RMSEA & RMR & CFI & NFI & GFI \\
\hline Teacher Form $(n=3095)$ & $25584.38^{* *}$ & 1115 & .08 & .06 & .97 & .97 & .75 \\
\hline$* *$ (
\end{tabular}

${ }^{* *} p<.01$. 


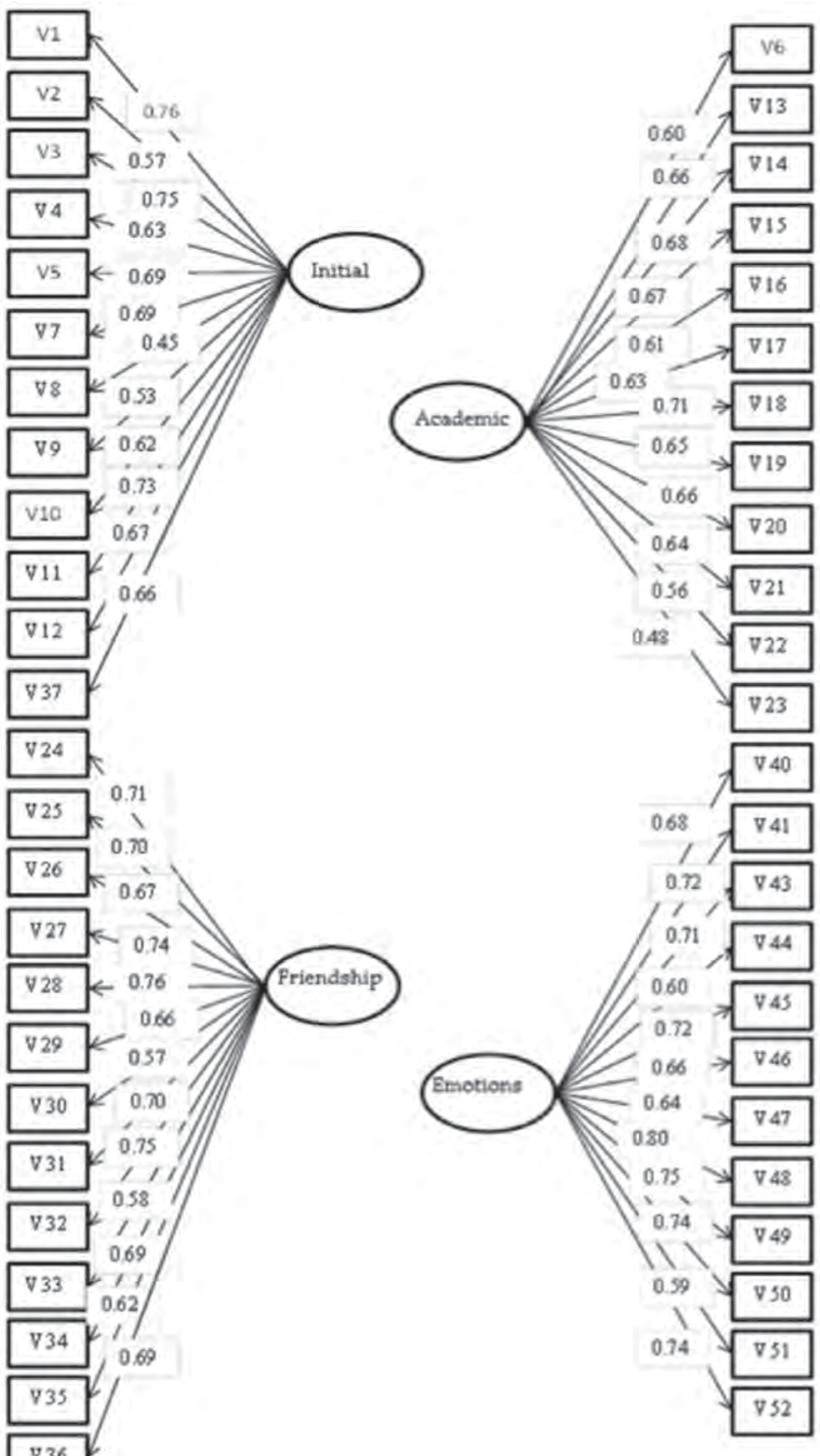

V36 
Table 7

Norm Sample PSSRS Teacher Form Alpha Coefficients

\begin{tabular}{llccrrr}
\hline & Age Group & Initial Skills & $\begin{array}{c}\text { Academic Support } \\
\text { Skills }\end{array}$ & Friendship Skills & $\begin{array}{c}\text { Emotional } \\
\text { Management Skills }\end{array}$ & $\begin{array}{c}\text { Total } \\
\text { Teacher Form }\end{array}$ \\
& 3 years $(\mathrm{n}=444)$ & .91 & .88 & .92 & .92 \\
& 4 years $(\mathrm{n}=833)$ & .90 & .90 & .93 & .92 & .97 \\
& 5 years $(\mathrm{n}=1818)$ & .89 & .88 & .91 & .91 \\
& $3-5$ years $(\mathrm{n}=3095)$ & .90 & .90 & .92 & .92 \\
\hline
\end{tabular}

From Table 7, the alpha coefficients calculated from the norm samples of the 3-year-old group range from .88 to .96 ; from .90 to .97 for the 4 -year-old group; from .88 to .96 for the 5 -year-old group; and from .90 to .96 for the whole norm sample. The PSSRS alpha coefficient obtained for the whole norm sample was determined at .96. These results show that the scale is reliable in terms of internal consistency. A five-point rating scale was used for answers to scale items, and a high score indicates that social skills are high.

\section{Data Analysis}

PSSRS norm values were obtained for the four factors and scale total of all ages. Norms were created for the total score and each sub-dimension in all age groups. Initially, we considered generating norms for the gender variable. However, according to two-factor ANOVA results on basic and mutual effects of age and gender, there is significant difference by age in social skills, but no significant difference by mutual effect of age and gender, and the eta-square values calculated as the effect size are as low as .01, although no significant difference was found between the factor scores by gender. Thus, gender norms were not generated separately for each age group, but only for all three age groups.

Children's social development skills are interpreted by percentile norm pie charts that include the total scale score and total scores obtained from sub-dimensions.

The norm study's objective is to determine Turkish norm values for the scale score and to assess children's social skills by comparing PSSRS raw scores and children's norm values. Scores obtained from the scale represent raw scores of a particular child. Raw scores are inadequate on their own for providing information about an individual's status on the measured qualification. Thus, an individual score gains importance when it is compared to the reference group's values.

Without doubt, the development speed and level of each child may differ. But by comparing children's raw scores and norm scores, we can consider strategies for development of that skill and use these strategies rather than judging the skill alone.

The percentile norm pies calculated at each dimension for 3-, 4- and 5-year-olds on PSSRS scores are shown below. The total score shows a raw score in all social skills, and the score of each subskill dimension shows the raw score of a particular sub-dimension. The children's raw scores will be interpreted by their percentile zone. Percentile pies will show the percentage of children in the field of social skills by Turkish norms. The children's percentile zone will guide teachers and parents as to the level of development in a particular area and the strategies that can be taken to develop their skills.

\section{Findings}

Descriptive statistics calculated for the PSSRS total and four-factor scores of three-year-old children are shown in Table 8.

Descriptive statistics for the 3-year-old group are shown in Table 8. Whether the distribution exhibits a significant deviation from normal distribution conditions is seen. Alpha reliability coefficients calculated for the whole scale and its sub-skill dimensions also look quite high (.88-.96).

Information on the percentile pies and the interpretation of raw scores corresponding to a particular percentile pie are provided in Appendix 1. Percentile pies were separately generated for the total PSSRS score and each sub-skill dimension.

Descriptive statistics calculated for PSSRS total and four-factor scores for 4-year-old children are shown in Table 9. 
Table 8

Descriptive Statistics of the PSSRS Teacher Version Scores for Norm Sample of 3-Year-Old Children

\begin{tabular}{|c|c|c|c|c|c|}
\hline & Initial Skills & $\begin{array}{l}\text { Academic Support } \\
\text { Skills } \\
\end{array}$ & Friendship Skills & $\begin{array}{c}\text { Emotional } \\
\text { Management Skills }\end{array}$ & Total \\
\hline Mean & 44.74 & 44.23 & 48,12 & 38,90 & 46,12 \\
\hline Confidence interval & 43.94-45.55 & $43.52-44.94$ & $47.29-48.95$ & $38.08-39.73$ & $45.38-46.84$ \\
\hline Standard error of the mean & .41 & .36 & .42 & .42 & .37 \\
\hline Standard Error of Measurement & 2.59 & 2.64 & 2.51 & 2.51 & 1.57 \\
\hline Median & 45 & 45 & 49 & 39 & 47 \\
\hline Mode & 48 & 45 & 49 & 36 & 48 \\
\hline Standard Variance & 8.64 & 7.63 & 8.89 & 8.82 & 7.83 \\
\hline Variance & 74.68 & 58.22 & 79.10 & 77.74 & 61.26 \\
\hline Skewness & -.51 & -.47 & -.47 & -.11 & -.70 \\
\hline Kurtosis & .10 & .44 & .14 & -.35 & .39 \\
\hline Range & 48 & 44 & 49 & 45 & 41 \\
\hline Minimum & 12 & 16 & 16 & 15 & 19 \\
\hline Maximum & 60 & 60 & 65 & 60 & 60 \\
\hline Reliability ( $\alpha$ ) & .91 & .88 & .92 & .92 & .96 \\
\hline \multirow[t]{3}{*}{ Percentile Pies } & 40 & 40 & 43 & 33 & 42 \\
\hline & 45 & 45 & 49 & 39 & 47 \\
\hline & 51 & 49 & 54 & 45 & 52 \\
\hline
\end{tabular}

Table 9

Descriptive Statistics of the PSSRS Total and Sub-Dimension Scores Obtained by 4-Year-Old Children

\begin{tabular}{|c|c|c|c|c|c|}
\hline & Initial Skills & $\begin{array}{l}\text { Academic Support } \\
\text { Skills } \\
\end{array}$ & Friendship Skills & $\begin{array}{c}\text { Emotional } \\
\text { Management Skills }\end{array}$ & Total \\
\hline $\mathrm{n}$ & 833 & 833 & 833 & 833 & 833 \\
\hline Mean & 47.98 & 47.20 & 51.74 & 42.40 & 48.67 \\
\hline Confidence interval & $47.45-48.51$ & $46.69-47.72$ & $51.17-52.32$ & $41.83-42.98$ & $48.21-49.14$ \\
\hline $\begin{array}{l}\text { Standard error of the mean } \\
\text { Standard error of measurement }\end{array}$ & $\begin{array}{l}.27 \\
2.46\end{array}$ & $\begin{array}{c}.26 \\
2.38\end{array}$ & $\begin{array}{c}.29 \\
2.23\end{array}$ & $\begin{array}{c}.29 \\
2.39\end{array}$ & $\begin{array}{c}.24 \\
1.18\end{array}$ \\
\hline Median & 48 & 47 & 52 & 43 & 49 \\
\hline Mode & 47 & 47 & 53 & 45 & 52 \\
\hline Standard Deviation & 7.77 & 7.53 & 8.42 & 8.44 & 6.84 \\
\hline Variance & 60.33 & 56.73 & 70.87 & 71.26 & 46.75 \\
\hline Skewness & -.74 & -.62 & -.55 & -.22 & -.68 \\
\hline Kurtosis & .90 & .54 & .18 & .09 & .58 \\
\hline Range & 46 & 44 & 43 & 47 & 40 \\
\hline Minimum & 14 & 16 & 22 & 13 & 20 \\
\hline Maximum & 60 & 60 & 65 & 60 & 60 \\
\hline Reliability ( $\boldsymbol{\alpha})$ & .90 & .90 & .93 & .92 & .97 \\
\hline \multirow[t]{3}{*}{ Percentile Pies } & 43 & 43 & 46 & 37 & 44 \\
\hline & 48 & 47 & 52 & 43 & 49 \\
\hline & 54 & 53 & 58 & 48 & 54 \\
\hline
\end{tabular}

Descriptive statistics of the 4-year-old norm group are shown in Table 9. Although the distribution exhibits a certain amount of deviation from normal distribution conditions, the deviation is considered tolerable. Alpha reliability coefficients calculated for the whole scale and its sub-skill dimensions also look quite high (.90-.97).

In Appendix 2 are the percentile pies of the 4-yearold norm group and the interpretation of raw scores that correspond to a particular percentile pie. Percentile pies were generated separately for the PSSRS total score and each sub-skill dimension.

Descriptive statistics calculated for the PSSRS total score and four-factor score for 5-year-old children are shown in Table 10. 


\begin{tabular}{|c|c|c|c|c|c|}
\hline \multicolumn{6}{|c|}{$\begin{array}{l}\text { Table } 10 \\
\text { Descriptive Statistics of PSSRS Teacher Form Total and Sub-Dimension Scores of Five-Year-Old Children }\end{array}$} \\
\hline & Initial Skills & $\begin{array}{l}\text { Academic Support } \\
\text { Skills }\end{array}$ & Friendship Skills & $\begin{array}{l}\text { Emotional } \\
\text { Management Skills }\end{array}$ & Total \\
\hline $\mathrm{n}$ & 1818 & 1818 & 1818 & 1818 & 1818 \\
\hline Average & 49.92 & 49.33 & 54.33 & 44.64 & 71.86 \\
\hline Confidence interval (\%95) & $49.59-50.25$ & $49.02-49.65$ & $53.99-54.66$ & $44.27-45.01$ & $69.54-74.18$ \\
\hline Standard error of the mean & .17 & .16 & .17 & .19 & 1.18 \\
\hline $\begin{array}{l}\text { Standard error of measurement } \\
\text { Median }\end{array}$ & $\begin{array}{c}2.38 \\
51\end{array}$ & $\begin{array}{c}2.36 \\
50\end{array}$ & $\begin{array}{c}2.17 \\
55\end{array}$ & $\begin{array}{c}2.41 \\
45\end{array}$ & $\begin{array}{c}10.10 \\
53\end{array}$ \\
\hline Mode & 60 & 49 & 65 & 46 & 54 \\
\hline Standard Deviation & 7.18 & 6.81 & 7.24 & 8.02 & 50.51 \\
\hline Variance & 51.62 & 46.34 & 52.48 & 64.36 & 2550.80 \\
\hline Skewness & -.78 & -.70 & -.61 & -.32 & 2.03 \\
\hline Kurtosis & .70 & .61 & .43 & .17 & 2.52 \\
\hline Range & 43 & 48 & 47 & 46 & 223 \\
\hline Minimum & 17 & 12 & 18 & 14 & 22 \\
\hline Maximum & 60 & 60 & 65 & 60 & 245 \\
\hline Reliability $(\alpha)$ & .89 & .88 & .91 & .91 & .96 \\
\hline \multirow[t]{3}{*}{ Percentile Pies } & 46 & 45 & 50 & 40 & 48 \\
\hline & 51 & 50 & 55 & 45 & 53 \\
\hline & 56 & 54 & 60 & 50 & 58 \\
\hline
\end{tabular}

Descriptive statistics for the 5-year-old norm group are shown in Table 10. While the distribution's subdimensions are tolerable, the statistics fail to fulfill normal distribution conditions when total scale scores are considered. Alpha reliability coefficients calculated for the whole scale and its sub-skill dimensions also look quite high (.88-.96).

In Appendix 3 are the percentile pies of the 5-yearold norm group and the interpretation of raw scores that correspond to a particular percentile pie. Percentile pies were generated separately for the PSSRS total score and each sub-skill dimension.

\section{Discussion}

This research aimed to develop a scale that generates valid and reliable scores for determination of children's social skills and to determine norms for those skills. Findings obtained for the validity and reliability of Preschool Social Skills Rating Scale (PSSRS) showed that the scale can be used as an auxiliary tool for determining children's social skill levels.
The following aspects of use and interpretation of results for the Preschool Social Skills Rating Scale (PSSRS) should be carefully considered:

- PSSRS gives general information on preschool children's social skills.

- In application of the PSSRS, certain of its aspects should be carefully considered.

- Activities aimed at supporting children's social skills should be planned by considering total scores.

- Each child should be assessed independently.

- Paying attention to children's ages and other developmental characteristics is important when interpreting scale results.

- Advancement achieved should be assessed by recording children's PSSRS scores and comparing the practices in later years. 


\section{References}

Akbaș, U. (2014). Farklı örneklem büyüklüklerinde ve kayıp veri örüntülerinde ölçeklerin psikometrik özelliklerinin kayip veri baş etme teknikleri ile incelenmesi (Doctoral dissertation, Ankara University, Turkey). Retrieved from https://tez.yok.gov.tr/UlusalTezMerkezi/

Akkök, F. (2006). İlköğretimde sosyal becerilerin geliștirilmesi (Anne-baba el kitabi). İstanbul: Özgür Yayınları.

Anderson, J. C., \& Gerbing, D. W. (1984). The effect of sampling error on convergence, improper solutions, and goodness-of-fit indices for maximum likelihood confirmatory factor analysis. Psychometrika, 49, 155-173.

Cole, D. A. (1987). Utility of confirmatory factor analysis in test validation research. Journal of Consulting and Clinical Psychology, 55, 1019-1031.

Çivitçi, A., \& Çivitçi, N. (2009). İlköğretim öğrencilerinde algılanan sosyal beceri ve mantıkdışı inançlar. İlköğretim Online, 8(2), 415-424. Retrieved from http://ilkogretimonline.org.tr/

Çubukçu, Z., \& Gültekin, M. (2000). İlköğretimde sosyal becerilerin gerçekleșme düzeyi. In IX. Eğitim Bilimleri Kongresi Bildiriler (Vol. 1, pp. 277-289). Erzurum.

Elias, M. J., Zins, J. E., Weissberg, R. P., Frey, K. S., Greenberg, M. T., Haynes, N. M. ... Shriver, T. P. (1997). Promoting social and emotional learning. Alexandria, VA: ASCD.

Gresham, F. M. (1981). Assessment of children's social skills. Journal of School Psychology, 19, 120-133.

Gresham, F. M. (1985). Behavior disorder assessment: Conceptual, definitional, and practical considerations. School Psychology Review, 14, 495-509.

Kamaraj, I. (2008). Erken çocukluk döneminde sosyal becerilerin gelișiminde öğretmenlerin rolü. Çoluk Çocuk Dergisi, 78, 6-8.
Kapıkıran, N., İvrendi, A., \& Adak, A. (2006). Okul öncesi çocuklarında sosyal beceri: Durum saptaması. Pamukkale Üniversitesi Eğitim Fakültesi Dergisi, 19(1), 20-28.

Marsh, H. W., Balla, J. R., \& McDonald, R. P. (1988). Goodness-of-fit indexes in confirmatory factor analysis: The effect of sample size. Psychological Bulletin, 103, 391-410.

McIntosh, R., Vaughn, S., \& Zaragoza, N. (1991). A review of social interventions for students with learning disabilities. Journal of Learning Disabilities, 24, 451-458.

Seven, S., \& Yoldaş, C. (2007). Sınıf öğretmeni adaylarının sosyal beceri düzeylerinin incelenmesi. Yüzüncü Y $l l$ Üniversitesi Eğitim Fakültesi Dergisi, 4(1), 1-18.

Sümer, N. (2000). Yapısal eşitlik modelleri: Temel kavramlar ve örnek uygulamalar. Türk Psikoloji Yazıları, 3(6) 49-74

Şimşek, Ü., Doymuş, K., \& Şimşek, U. (2008). İşbirlikli öğrenme yöntemi üzerine derleme çalışması: II. İşbirlikli ögrrenme yönteminin sinıf ortamında uygulanması. Erzincan Eğitim Fakültesi Dergisi, 10(1), 123-142.

Tryfos, P. (1996). Sampling methods for applied research. New York, NY: John Wiley and Sons.

Verduyn, C. M., Lord, W., \& Forrest, G. C. (1990). Social skills training in schools: An evaluation study. Journal of Adolescence, 13, 3-16.

Wortham, S. C. (1998). Early childhood curriculum. Virginia, VA: Prentice Hall.

Yüksel, G. (2001). Öğretmenlerin sahip olmaları gereken davranış olarak sosyal beceri. Milli Eğitim Dergisi, 150. Retrieved from http://dhgm.meb.gov.tr/yayimlar/dergiler/ Milli_Egitim_Dergisi/150/yuksel.htm 
Appendix 1

Norm Pie Percentiles and Score Intervals of the 3-Year-Old Children's Group, Definitions, and Explanations

\begin{tabular}{|c|c|c|c|}
\hline $\begin{array}{c}\text { SkillPie Per- } \\
\text { centile }\end{array}$ & $\begin{array}{c}\text { Score } \\
\text { Interval }\end{array}$ & Definition & Explanation \\
\hline
\end{tabular}

$\mathrm{X} \geq 75 \quad 51+\quad$ The development level of the initial skills of the child is
75\% or higher than the group norm.

The development in the social skills of the child is at a sufficient and expected level.

$50 \% \leq \mathrm{X}<75 \% \quad 45-50 \quad$ than their peers. Although there is no problem in general, new/additional education opportunities should be provided to develop these skills and the child should be periodically monitored.

Initial Skills The development level of the initial skills of the child is less than $50 \%$ and greater than or equal to $25 \%$ of the group $25 \% \leq \mathrm{X}<50 \% \quad 40-44 \quad$ norm. Social skills development of the child is slower than their peers, and the development of these skills should be

supported with new/additional education opportunities.
The development level of the initial skills of the child is

supported with new/additional education opportunities.
The development level of the initial skills of the child is less than $25 \%$ of the group norm. Social skills development $\mathrm{X}<25 \% \quad 0-39 \quad$ of the child is quite slower than their peers. Development of these skills should be supported by new and additional education opportunities. Parents should cooperate closely on this subject. The child should be constantly monitored.

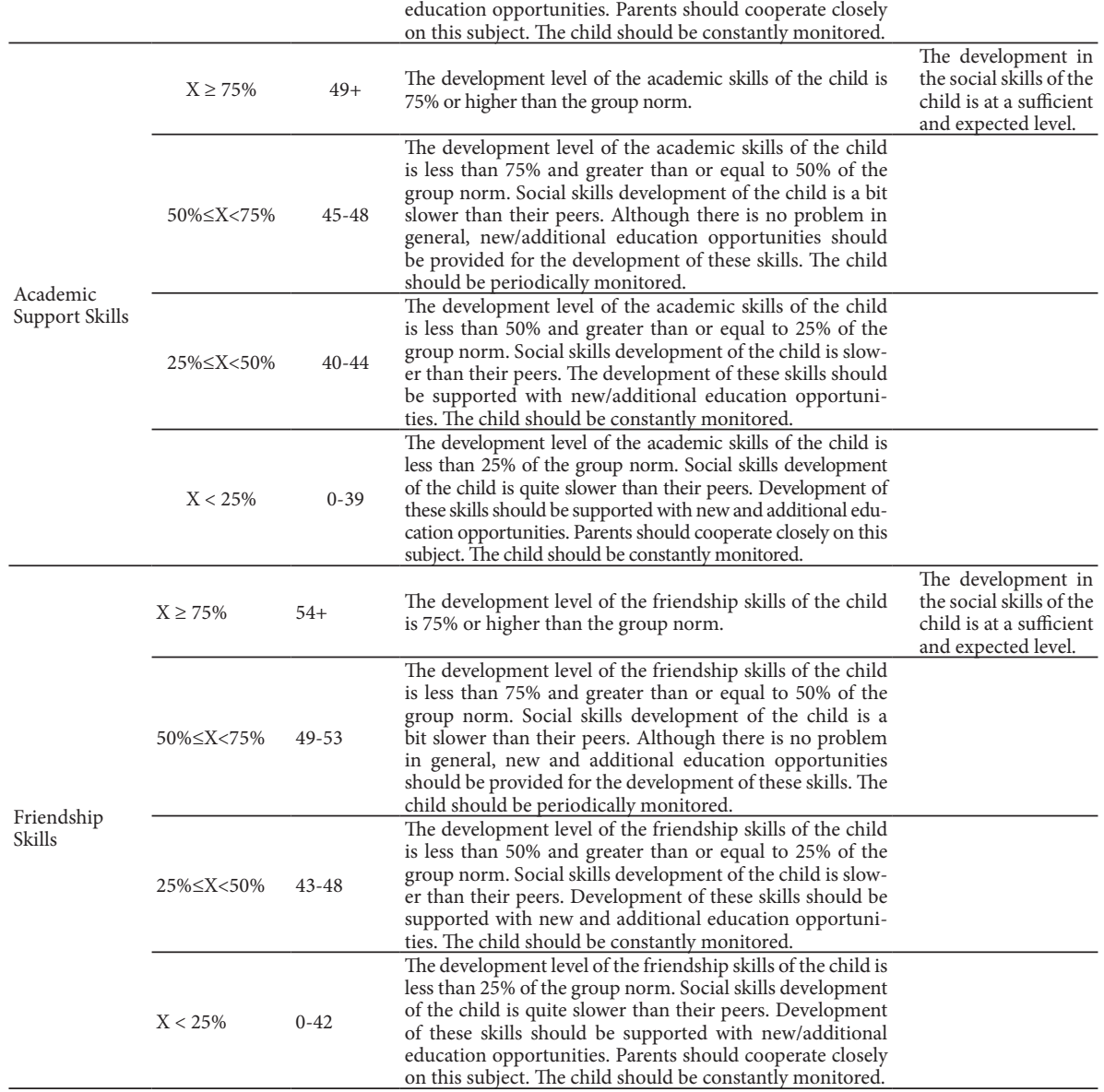


Appendix 1

Norm Pie Percentiles and Score Intervals of the 3-Year-Old Children's Group, Definitions, and Explanations

\begin{tabular}{cccc}
\hline $\begin{array}{c}\text { SkillPie Per- } \\
\text { centile }\end{array}$ & $\begin{array}{c}\text { Score } \\
\text { Interval }\end{array}$ & Definition & Explanation \\
\hline & & & \\
& & & $\begin{array}{l}\text { The development level of the emotional management skills } \\
\text { of the child is } 75 \% \text { or higher than the group norm. }\end{array}$
\end{tabular}

The development in

the social skills of the child is at a sufficient and expected level.

Social skills development of the child is a bit slower than their peers. Although there is no problem

The development level of emotional management skills of the child is less than $75 \%$ and greater than or equal to $50 \%$ of the group norm.

in general, new/additional education opportunities should be provided for the development of these skills and the child should be peri-

Emotional Management Skills

The development level of emotional management skills of odically monitored. $25 \% \leq \mathrm{X}<50 \% \quad 33-38 \quad \begin{aligned} & \text { the child is less than } 50 \% \text { and greater than or equal to } 25 \% \\ & \text { of the group norm. Social skills development of the child } \\ & \text { is slower than her peers, and the development of these }\end{aligned}$ skills should be supported with new/additional education opportunities. The child should be constantly monitored.

The development level of emotional management skills of the child is less than $25 \%$ of the group norm. Social skills development of the children is a quite slower than their

$\mathrm{X}<25 \% \quad 0-32 \quad$ peers. Development of these skills should be supported with new and additional education opportunities. The parents should be closely cooperated on this subject. The child should be constantly monitored.

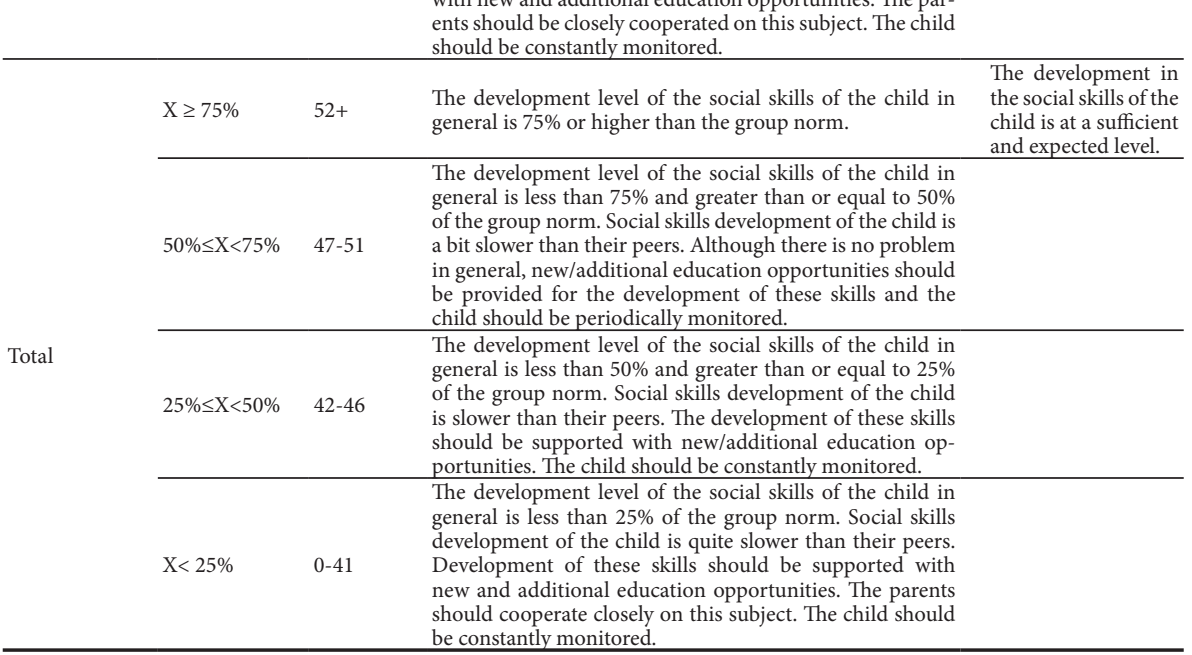


Appendix 2

Norm Pie Percentiles and Score Intervals of the 4-Year-Old Children's Group, Definitions and Explanations Skill Pie Percentile Score Definition

Explanation

\begin{tabular}{ll}
$\mathrm{X} \geq 75 \%$ & $54+\quad \begin{array}{l}\text { The development level of the initial skills of the child } \\
\text { is } 75 \% \text { or higher than the norm group. }\end{array}$ \\
\hline
\end{tabular}

The development in the social skills of the child is at a sufficient

The development level of the initial skills of the child and expected level. of the group norm. Social skills development of the

$50 \% \leq \mathrm{X}<75 \% \quad 48-53 \quad$ child is a bit slower than their peers. Although there is no problem in general, new/additional education opportunities should be provided for the development of these skills and the child should be periodically monitored.

The development level of the initial skills of the child is less than $50 \%$ and greater than or equal to $25 \%$ of the group norm. Social skills development of the

Initial Skills

$25 \% \leq \mathrm{X}<50 \% \quad 43-47$ child is slower than their peers. Development of these skills should be supported with new and additional education opportunities. The child should be constantly monitored.

The development level of the initial skills of the child is less than $25 \%$ of the group norm. Social $\mathrm{X}<25 \% \quad 0-42 \quad$ their peers. Development of these skills should be supported with new/additional education opportunities. Parents should cooperate closely on this subject. The child should be constantly monitored.

\begin{tabular}{|c|c|c|c|c|}
\hline \multirow{4}{*}{$\begin{array}{l}\text { Academic } \\
\text { Support } \\
\text { Skills }\end{array}$} & $X \geq 75 \%$ & $53+$ & $\begin{array}{l}\text { The development level of the academic skills of the } \\
\text { child is } 75 \% \text { or higher than the group norm. }\end{array}$ & $\begin{array}{l}\text { The development in the socia } \\
\text { skills of the child is at a sufficien } \\
\text { and expected level. }\end{array}$ \\
\hline & $50 \% \leq X<75 \%$ & $47-52$ & $\begin{array}{l}\text { The development level of the academic skills of the } \\
\text { child is less than } 75 \% \text { and greater than or equal to } \\
50 \% \text { of the group norm. Social skills development of } \\
\text { the child is a bit slower than their peers. Although } \\
\text { there is no problem in general, new/additional ed- } \\
\text { ucation opportunities should be provided for the } \\
\text { development of these skills and the child should be } \\
\text { periodically monitored. }\end{array}$ & \\
\hline & $25 \% \leq X<50 \%$ & $43-46$ & $\begin{array}{l}\text { The development level of the academic skills of the } \\
\text { child is less than } 50 \% \text { and greater than or equal to } \\
25 \% \text { of the group norm. Social skills development } \\
\text { of the child is slower than their peers. Development } \\
\text { of these skills should be supported with new/addi- } \\
\text { tional education opportunities. The child should be } \\
\text { constantly monitored. }\end{array}$ & \\
\hline & $X<25 \%$ & $0-42$ & $\begin{array}{l}\text { The development level of the academic skills of the } \\
\text { child is less than } 25 \% \text { of the group norm. Social } \\
\text { skills development of the child is quite slower than } \\
\text { their peers. Development of these skills should be } \\
\text { supported with new/additional education oppor- } \\
\text { tunities. Parents should cooperate closely on this } \\
\text { subject. The child should be constantly monitored. }\end{array}$ & \\
\hline \multirow{4}{*}{$\begin{array}{l}\text { Friendship } \\
\text { Skills }\end{array}$} & $X \geq 75 \%$ & $58+$ & $\begin{array}{l}\text { The development level of the friendship skills of the } \\
\text { child is } 75 \% \text { or higher than the group norm. }\end{array}$ & $\begin{array}{l}\text { The development in the socia } \\
\text { skills of the child is at a sufficien } \\
\text { and expected level. }\end{array}$ \\
\hline & $50 \% \leq X<75 \%$ & $52-57$ & $\begin{array}{l}\text { The development level of the friendship skills of the } \\
\text { child is lower than } 75 \% \text { and greater than or equal to } \\
50 \% \text { of the group norm. Social skills development of } \\
\text { the child is a bit slower than their peers. Although } \\
\text { there is no problem in general, new/additional ed- } \\
\text { ucation opportunities should be provided for the } \\
\text { development of these skills and the child should be } \\
\text { periodically monitored. }\end{array}$ & \\
\hline & $25 \% \leq X<50 \%$ & $46-51$ & $\begin{array}{l}\text { The development level of the friendship skills of the } \\
\text { child is lower than } 50 \% \text { and greater than or equal to } \\
25 \% \text { of the group norm. Social skills development } \\
\text { of the child is slower than their peers. Development } \\
\text { of these skills should be supported with new/addi- } \\
\text { tional education opportunities. The child should be } \\
\text { constantly monitored. }\end{array}$ & \\
\hline & $X<25 \%$ & $0-45$ & $\begin{array}{l}\text { The development level of the friendship skills of } \\
\text { the child is less than } 25 \% \text { of the group norm. Social } \\
\text { skills development of the child is quite slower than } \\
\text { their peers. Development of these skills should be } \\
\text { supported with new/additional education oppor- } \\
\text { tunities. Parents should cooperate closely on this } \\
\text { subject. The child should be constantly monitored. }\end{array}$ & \\
\hline
\end{tabular}


Appendix 2

Norm Pie Percentiles and Score Intervals of the 4-Year-Old Children's Group, Definitions and Explanations

Skill Pie Percentile Score
Definition Explanation

The development level of the emotional manage$48+\quad$ ment skills of the child is $75 \%$ or higher than the ment skills of
group norm.

The development in the social

The development level of emotional management skills of the child is at a sufficient skills of the child is less than $75 \%$ and greater than or equal to $50 \%$ of the group norm. Social skills

$50 \% \leq \mathrm{X}<75 \% \quad 43-47$ development of the child is a bit slower than their peers. Although there is no problem in general, new/additional education opportunities should be provided for the development of these skills and the child should be periodically monitored.

Emotional

Management

Skills

$25 \% \leq X<50 \%$

$37-42$

The development level of emotional management skills of the child is less than $50 \%$ and greater than or equal to $25 \%$ of the group norm. Social skills de-

velopment of the child is slower than their peers. Development of these skills should be supported with new/additional education opportunities. The child should be constantly monitored.

The development level of emotional management skills of the child is less than $25 \%$ of the group norm. Social skills development of the child is quite slower $\mathrm{X}<25 \% \quad 0-36 \quad$ than their peers. Development of these skills should be supported with new/additional education opportunities, and the parents should cooperate closely on this subject. The child should be constantly monitored.

$\mathrm{X} \geq 75 \% \quad 54+\quad \begin{aligned} & \text { The development level of the social skills of the child in } \\ & \text { general is } 75 \% \text { or higher than the norm group. }\end{aligned}$

The development level of the social skills of the child in general is less than $75 \%$ and greater than or equal to $50 \%$ of the group norm. Social skills development of the child is a bit slower than their peers. Although

$50 \% \leq \mathrm{X}<75 \% \quad 49-53 \quad \begin{aligned} & \text { of the child is a bit slower than their peers. Although } \\ & \text { there is no problem in general, new/additional ed- }\end{aligned}$

$50 \% \leq \mathrm{X}<75 \% \quad 49-53 \quad \begin{aligned} & \text { of the child is a bit slower than their peers. Although } \\ & \text { there is no problem in general, new/additional ed- } \\ & \text { ucation opportunities should be provided for the }\end{aligned}$ development of these skills and the child should be periodically monitored.

The development level of the social skills of the child

Total in general is less than $50 \%$ and greater than or equal to $25 \%$ of the group norm. Social skills development

$25 \% \leq \mathrm{X}<50 \% \quad 44-48 \quad$ of the child is slower than their peers. Development of these skills should be supported with new/additional education opportunities. The child should be constantly monitored.

The development level of the social skills of the child

in general is less than $25 \%$ of the group norm. Social skills development of the child is quite slower than

$\mathrm{X}<25 \% \quad 0-43 \quad$ their peers. Development of these skills should be supported with new/additional education opportunities. Parents should cooperate closely on this subject. The child should be constantly monitored.
The development in the social skills of the child is at a sufficient and expected level. 
Appendix 3

Norm Pie Percentiles and Score Intervals of the 4-Year-Old Children's Group, Definitions and Explanations Skill Pie Percentile Score

$\mathrm{X} \geq 75 \% \quad 56+\quad$ The development level of the initial skills of the child
is $75 \%$ or higher than the group norm. Explanation

The development level of the initial skills of the child is less than $75 \%$ and greater than or equal to $50 \%$ of the group norm. Social skills development of the $50 \% \leq \mathrm{X}<75 \% \quad 51-55$ child is a bit slower than their peers. Although there is no problem in general, new/additional education opportunities should be provided for the development of these skills and the child should be periodically monitored.

The development level of the initial skills of the child is less than $50 \%$ and greater than or equal to $25 \%$ of the group norm. Social skills development

Initial Skills

46-50 of the child is slower than their peers. Development of these skills should be supported with new/additional education opportunities. The child should be constantly monitored.

The development level of the initial skills of the child is less than $25 \%$ of the group norm. Social skills development of the child is quite slower than

$\mathrm{X}<25 \% \quad 0-45$ their peers. Development of these skills should be supported with new/additional education opportunities. Parents should cooperate closely on this subject. The child should be constantly monitored.

\begin{tabular}{|c|c|c|c|c|}
\hline & & & $\begin{array}{l}\text { supported with new/additional education oppor- } \\
\text { tunities. Parents should cooperate closely on this } \\
\text { subject. The child should be constantly monitored. }\end{array}$ & \\
\hline \multirow{4}{*}{$\begin{array}{l}\text { Academic } \\
\text { Support } \\
\text { Skills }\end{array}$} & $X \geq 75 \%$ & $54+$ & $\begin{array}{l}\text { The development level of the academic skills of the } \\
\text { child is } 75 \% \text { or higher than the group norm. }\end{array}$ & $\begin{array}{l}\text { The development in the social } \\
\text { skills of the child is at a sufficient } \\
\text { and expected level. }\end{array}$ \\
\hline & $50 \% \leq X<75 \%$ & $50-53$ & $\begin{array}{l}\text { The development level of the academic skills of the } \\
\text { child is less than } 75 \% \text { and greater than or equal to } \\
50 \% \text { of the group norm. Social skills development of } \\
\text { the child is a bit slower than their peers. Although } \\
\text { there is no problem in general, new/additional ed- } \\
\text { ucation opportunities should be provided for the } \\
\text { development of these skills and the child should be } \\
\text { periodically monitored. }\end{array}$ & \\
\hline & $25 \% \leq X<50 \%$ & $45-49$ & $\begin{array}{l}\text { The development level of the academic skills of the } \\
\text { child is less than } 50 \% \text { and greater than or equal to } \\
25 \% \text { of the group norm. Social skills development } \\
\text { of the child is slower than their peers. Development } \\
\text { of these skills should be supported with new/addi- } \\
\text { tional education opportunities. The child should be } \\
\text { constantly monitored. }\end{array}$ & \\
\hline & $X<25 \%$ & $0-44$ & $\begin{array}{l}\text { The development level of the academic skills of the } \\
\text { child is less than } 25 \% \text { of the group norm. Social } \\
\text { skills development of the child is quite slower than } \\
\text { their peers. Development of these skills should be } \\
\text { supported with new/additional education oppor- } \\
\text { tunities. Parents should cooperate closely on this } \\
\text { subject. The child should be constantly monitored. }\end{array}$ & \\
\hline \multirow{4}{*}{$\begin{array}{l}\text { Friendship } \\
\text { Skills }\end{array}$} & $X \geq 75 \%$ & $60+$ & $\begin{array}{l}\text { The development level of the friendship skills of the } \\
\text { child is } 75 \% \text { or higher than the group norm. }\end{array}$ & $\begin{array}{l}\text { The development in the social } \\
\text { skills of the child is at a sufficient } \\
\text { and expected level. }\end{array}$ \\
\hline & $50 \% \leq X<75 \%$ & $55-59$ & $\begin{array}{l}\text { The development level of the friendship skills of the } \\
\text { child is less than } 75 \% \text { and greater than or equal to } \\
50 \% \text { of the group norm. Social skills development of } \\
\text { the child is a bit slower than their peers. Although } \\
\text { there is no problem in general, new/additional ed- } \\
\text { ucation opportunities should be provided for the } \\
\text { development of these skills and the child should be } \\
\text { periodically monitored. }\end{array}$ & \\
\hline & $25 \% \leq X<50 \%$ & $50-54$ & $\begin{array}{l}\text { The development level of the friendship skills of the } \\
\text { child is less than } 50 \% \text { and greater than or equal to } \\
25 \% \text { of the group norm. Social skills development } \\
\text { of the child is slower than their peers. Development } \\
\text { of these skills should be supported with new/addi- } \\
\text { tional education opportunities. The child should be } \\
\text { constantly monitored. }\end{array}$ & \\
\hline & $X<25 \%$ & $0-49$ & $\begin{array}{l}\text { The development level of the friendship skills of } \\
\text { the child is less than } 25 \% \text { of the group norm. Social } \\
\text { skills development of the child is quite slower than } \\
\text { their peers. Development of these skills should be } \\
\text { supported with new/additional education oppor- } \\
\text { tunities. Parents should cooperate closely on this } \\
\text { subject. The child should be constantly monitored. }\end{array}$ & \\
\hline
\end{tabular}


Appendix 3

Norm Pie Percentiles and Score Intervals of the 4-Year-Old Children's Group, Definitions and Explanations

Skill Pie Percentile Score
Definition Explanation

The development level of the emotional manage$50+$ ment skills of the child is $75 \%$ or higher than the group norm.

The development in the social

The development level of emotional management skills of the child is at a sufficient skills of the child is less than $75 \%$ and greater than or equal to $50 \%$ of the group norm. Social skills

development of the child is a bit slower than their peers. Although there is no problem in general, new/additional education opportunities should be provided for the development of these skills and the child should be periodically monitored.

Emotional

Management

Skills

$25 \% \leq \mathrm{X}<50 \%$

the chanement skills of the child is less than $50 \%$ and greater than or equal to $25 \%$ of the group norm. Social skills de-

40-44 velopment of the child is slower than their peers. Development of these skills should be supported with new/additional education opportunities. The child should be constantly monitored.

The development level of emotional management skills of the child is less than $25 \%$ of the group norm.

Social skills development of the child is quite slower

$\mathrm{X}<25 \% \quad 0-39$ than their peers. Development of these skills should be supported with new/additional education opportunities. Parents should cooperate closely on this subject. The child should be constantly monitored.

$\mathrm{X} \geq 75 \% \quad 58+\quad$ The development level of the social skills of the child in general is $75 \%$ or higher than the group norm.

The development in the social skills of the child is at a sufficient and expected level.

The development level of the social skills of the child in general is less than $75 \%$ and greater than or equal to $50 \%$ of the group norm. Social skills development

$50 \% \leq \mathrm{X}<75 \% \quad 53-57$ of the child is a bit slower than their peers. Although there is no problem in general, new/additional education opportunities should be provided for the development of these skills and the child should be periodically monitored.

The development level of the social skills of the child in general is less than $50 \%$ and greater than or equal to $25 \%$ of the group norm. Social skills development

$25 \leq \mathrm{X}<50 \quad 48-52$ of the child is slower than their peers. Development of these skills should be supported with new/additional education opportunities. The child should be constantly monitored.

The development level of the social skills of the child in general is less than $25 \%$ of the group norm. Social skills development of the child is quite slower than

$\mathrm{X}<25 \%$ 0-47 their peers. Development of these skills should be supported with new/additional education opportunities. Parents should cooperate closely on this subject. The child should be constantly monitored. 